\title{
Law and the Realisation of Human Rights: Insights from Indonesia's Education Sector
}

\author{
ANDREW ROSSER* \\ University of Adelaide
}

\begin{abstract}
Do justiciable legal frameworks for the protection of human rights (JLFPHR) promote the realisation of human rights? This paper considers this question by examining a set of recent Indonesian court cases related to the right to education. It argues that citizens in these cases successfully used Constitutional provisions related to education rights to challenge government policies that undermined these rights because: (i) they encountered judges sympathetic to their cause; (ii) they had access to support structures for legal mobilisation (SSLMS); and (iii) they engaged in simultaneous political mobilisation that created a broader political climate conducive to judicial activism and policy change. As such, it is argued, these cases confirm comparative findings that judicial activism and SSLMs are important preconditions for JLFPHR to contribute to the realisation of human rights through courts, at least in contexts where court cases are costly; and point to the important role that political mobilisation can play in creating a broader political climate favourable to judicial activism and policy change. In policy terms, the implication is that JLFPHR need to be accompanied by efforts to nurture SSLMs, judicial activism and strategies that blend legal and political mobilisation.
\end{abstract}

Keywords: Indonesia, law, education, human rights, courts, 1945 Constitution, politics

\section{Introduction}

Do justiciable legal frameworks for the protection of human rights (JLFPHR) promote the realisation of human rights in developing countries? If so, why and under what conditions? If not, why not?

Recent years have seen considerable debate over these questions, reflecting the growing prominence of rights-based approaches to development (RBAs) in official development discourse and moves by many developing countries to enshrine human rights in national Constitutions and laws (Keith et al., 2009). On one side of this debate, advocates of RBAs have argued that JLFPHRs are "a tremendous force for protecting the rights of those living in poverty to challenge and gain power" because they act "as a shield against the kinds of harm that cause or perpetuate poverty, and as a weapon for helping people increase their freedom" (Khan, 2009, p. 203). JLFPHR, they assume, ensure that government policies protect human rights, bureaucracies implement rights, and, as a result, rights indicators (such as levels of political freedom, health service utilisation rates and school enrolment rates) improve.

By contrast, scholars working in the "law and social movements" tradition have argued that JLFPHR have little positive effect on the realisation of rights because courts have generally been captured by conservative elements unsympathetic to rights-related causes, making it difficult for ordinary citizens and rights activists to secure rights-friendly court judgments (Scheingold, 1974; Rosenberg, 1991; McCann, 1994). JLFPHR have only

\footnotetext{
*Correspondence Address: andrew.rosser@adelaide.edu.au
} 
This is an Accepted Manuscript of an article published by Taylor \& Francis in Asian Studies Review on 27 April 2015, available online:

http://www.tandfonline.com/doi/full/10.1080/10357823.2015.1025462

promoted the realisation of human rights, it is argued, when they have spurred political mobilisation around rights issues by, for instance, perpetuating the "myth of rights" (that is, the notion that once rights are legally recognised, they can be effectively enforced through the courts and realised in practice) (Scheingold, 1974) and/or enhancing networking, interaction and cooperation between members of rights movements (McCann, 1994; Silverstein, 2003, p. 413; Joshi, 2010).

A third group of scholars has suggested that the impact of JLFPHR on court judgments is contingent upon particular political and social preconditions. Epp $(1996 ; 1998)$, for instance, has argued that litigants will secure rights-friendly outcomes through courts only if they have access to "support structures for legal mobilisation" (SSLMs) consisting of: (i) organisational "repeat players" who have extensive experience in using the court system (e.g. state-owned legal aid organisations, legal aid NGOs); (ii) financing (including from private sources but especially from government sources); and (iii) (cause) lawyers willing to pursue human rights cases (see also Flemming and Krutz, 2002). Wilson (2009; 2011) has argued that SSLMs have played little role in countries such as Colombia and Costa Rica where superior courts are accessible and cheap ${ }^{1}$ and poor and disadvantaged citizens have consequently been able to access them directly without assistance. Yet such circumstances are rare. Scholars in this third group have also emphasised the role of judicial activism in producing rights-friendly court decisions, depicting judges as strategic actors who are willing to issue rights-friendly decisions if they are sympathetic to the relevant cause, believe that protecting rights will benefit their court in some way (e.g. by enhancing its legitimacy), and can do so without triggering a severe political backlash against themselves or their court (Bhagwati, 1984; Baxi, 1985; Brinks and Gauri, 2008; Butt, 2012a). Only when rights victims encounter such judges, it is argued, will they secure rights-friendly judgments.

This paper contributes to this debate by analysing a set of recent Indonesian court cases related to the right to education, a right that was enshrined in Indonesia's 1945 Constitution in 2000. It argues that the citizens involved in these court cases were able to secure rights-friendly judgments, achieve changes in government education policy, and, in so doing, promote realisation of the right to education in Indonesia for three reasons. First, they encountered sympathetic judges in court either because they pursued their concerns through the Constitutional Court, a court that has had a progressive approach to human rights issues, or they happened to be allocated such judges in regular courts. Second, they had support from legal aid and anti-corruption NGOs that provided them with the required organisational, financial and technical resources to launch and sustain their court cases - in other words they had access to SSLMs. Third, they engaged in simultaneous political mobilisation that secured public support for their cause, created a broader political climate conducive to judicial activism, and placed pressure on the central government to change its policies.

In terms of the above debate, the paper thus broadly favours the views of the third group of scholars. It suggests that JLFPHR are neither self-activating (as advocates of rightsbased approaches to development assume) nor largely inconsequential except via political mobilisation (as law and social movements scholars argue) but rather effective in promoting rights through courts when ordinary citizens have access to SSLMs (specifically in contexts where court cases are costly) and encounter activist judges in court. At the same time, however, it also points to the important role that political mobilisation can play in creating a broader political climate favourable to judicial activism and policy change, a variable emphasised more in the "law and social movements" literature. In terms of policy, the paper thus suggests a need to ensure that the introduction of JLFPHR is accompanied by the nurturing of SSLMs and judicial activism and the formulation of strategies that blend legal 
This is an Accepted Manuscript of an article published by Taylor \& Francis in Asian Studies Review on 27 April 2015, available online:

http://www.tandfonline.com/doi/full/10.1080/10357823.2015.1025462

and political mobilisation rather than view them as mutually exclusive alternatives, as in some of the literature.

In presenting this argument, I begin by briefly examining the nature of Indonesian law vis-à-vis the right to education, the country's court system, and the political dynamics of education policymaking in Indonesia. This is to establish the historical and political context for the court cases examined in the paper. I then examine these cases according to the two policy issues to which they relate - namely, the national school exam and the autonomy of educational institutions. In the final section, I consider the theoretical and policy implications of the paper's analysis.

Before beginning with this analysis, however, it is important to note that this paper is not directly concerned with the impact of JLFPHR on improvements in school participation rates, enrolment rates and other measures of the extent to which the right to education is realised in practice. Nor is it directly concerned with the emergence of what Epp (2010, pp. 2-3) has called "legalised accountability" - that is, "the law-styled attempt to bring bureaucratic practice into line with emerging legal norms"; in other words, it is not concerned with the bureaucratic implementation of rights. Rather, the paper is concerned only with the extent to which JLFPHR are translated into government policies as expressed in laws and regulations. If one conceives of the process of realising rights as having three stages - (i) the translation of rights-in-law (including rights provided for in Constitutions) into government policies; (ii) the bureaucratic implementation of these policies; and (iii) improvements in rights-related indicators - then this paper is concerned only with the first stage. Separate analyses are required to explore the contribution of JLFPHR to the second and third stages of rights realisation. ${ }^{2}$

\section{The Context}

\section{Indonesian law vis-à-vis the right to education}

Indonesian law has explicitly provided citizens with a right to education only fairly recently. As originally formulated in 1945, the country's 1945 Constitution $^{3}$ provided Indonesian citizens with a right to "instruction" (pengadjaran) (Article 31(1)), not "education" (pendidikan). ${ }^{4}$ Law 19/PNPS/1965 on Principles of a Pancasila National Education System, the main piece of education legislation during the final days of Sukarno's Guided Democracy and the first two decades of the New Order regime (1965-98), contained no statement of citizens' rights vis-à-vis either education or instruction, nor any definitions of these two terms. Law 2/1989 on a National Education System, which was introduced by the New Order in 1989 to replace Law 19/PNPS/1965 altered things a little. Article 6 stated that "Each citizen has a right to the greatest opportunity (kesempatan yang seluas-luasnya) to pursue an education in order to obtain knowledge, ability and skill that is at least equivalent to the knowledge, ability and skill of a basic education graduate". At most this article provided for a right to basic education, and, given the uncertain meaning of "greatest opportunity", it is not clear if it even did this. ${ }^{5}$

Following the collapse of the New Order in 1998, Indonesian law-makers enacted a series of new pieces of legislation that provided, much more explicitly, for a right to education. These included Supreme Deliberative Council (MPR) Decision 17/1998 on 
This is an Accepted Manuscript of an article published by Taylor \& Francis in Asian Studies Review on 27 April 2015, available online:

http://www.tandfonline.com/doi/full/10.1080/10357823.2015.1025462

Human Rights and Law 39/1999 on Human Rights. Most importantly, for our purposes, between 1999 and 2002, the MPR amended the 1945 Constitution to incorporate, among other things, two new provisions stating that citizens have "a right to obtain an education" (i.e. Articles 28C and 31(1)). The amendments to the 1945 Constitution also included a new provision requiring the government to fund compulsory basic education (Article 31(2)), effectively creating a right to free basic education. In the Indonesian context, basic education encompasses the years of primary school (grades 1 to 6) and junior secondary school (grades 7 to 9). These Constitutional changes were subsequently reaffirmed in a number of laws including Law 23/2002 on Child Protection, Law 20/2003 on a National Education System, and Law 11/2005 on the Ratification of the International Covenant on Economic, Social and Cultural Rights (ICESCR).

Despite the relatively recent incorporation of the right to education into Indonesian law, then, both it and the right to free basic education were both well established under Indonesian law by the mid-2000s when the court cases examined below were launched by citizens and rights activists.

\section{Indonesia's court system}

Indonesia's court system consists of (i) the Supreme Court (Mahkamah Agung), the country's highest court; (ii) various general and specialised courts that operate under its supervision; and (iii) the Constitutional Court (Mahkamah Konstitusi). The Supreme Court is, by virtue of its position at the apex of the court system, responsible for supervising and managing all lower courts. It has the authority to, among other things, provide warnings and advice to judges in lower courts; hear and rule on cases on appeal (kasasi) from lower courts; and carry out judicial review of implementing regulations to determine their consistency with laws (undang-undang). The courts that fall under its jurisdiction include general courts (which deal with private and commercial law matters); religious courts (which deal primarily with family and inheritance matters for Muslims); military courts (which deal with criminal matters involving members of the military); and state administrative courts (which deal with disputes over administrative decisions). They also include relatively new special courts such as the Human Rights Court, the Anti-Corruption Court and the Tax Court (ASEAN Law Association, 2005).

The Constitutional Court has the authority to carry out judicial review of laws - that is, legislation passed by the national parliament (undang-undang) - and their individual articles to determine whether they are consistent with the amended 1945 Constitution. If it deems that they are not, it can rule them legally invalid, effectively removing them from the statute books. Its other powers include resolving conflicts over general election results, deciding in disputes between state institutions, and determining whether the President or Vice-President has committed treason, corruption, bribery or some other serious criminal offence as part of impeachment procedures (Asshiddiqie, 2006, pp. 5-6; ASEAN Law Association, 2005).

For our purposes, three points about Indonesia's court system are particularly important. The first is that Indonesian courts are generally characterised by high levels of corruption, inefficiency, and vulnerability to political interference, with the result that they have not, in most cases, been responsive to rights-related concerns (Goodpaster, 2002, pp. 96-97; Susanti, 2008, pp. 224-25). The Supreme Court is often singled out for criticism in this respect (Pompe, 2005). During the New Order period, the government interfered extensively in court matters and encouraged the development of a culture of corruption within the judiciary (Thoolen, 1987). At the same time, poor resourcing meant that decision- 
This is an Accepted Manuscript of an article published by Taylor \& Francis in Asian Studies Review on 27 April 2015, available online:

http://www.tandfonline.com/doi/full/10.1080/10357823.2015.1025462

making processes moved slowly. Evidence suggests that corruption and inefficiency remain serious problems within the judiciary in the post-New Order period: the corruption perception surveys carried out by Transparency International Indonesia, for instance, indicate that the judiciary is regarded as one of the most corrupt government institutions in the country (Susanti, 2008, p. 225). Some commentators have argued that the courts are run by a judicial "mafia" (e.g. Ida, 2010).

The second point is that, despite this general pattern, some specific courts have developed a reputation for fairness, efficiency, professionalism and a willingness to support rights-oriented causes, reflecting the broader process of democratic reform that has followed the fall of the New Order. A key aspect of reform efforts was the creation of new, specialised courts that were designed in such a way as to reduce the prospects for political interference and control by the judicial mafia. ${ }^{6}$ The most important court in this respect has been the Constitutional Court. This court has benefited from judicial selection and funding arrangements that have enhanced its autonomy from the government and the Supreme Court. Rather than being captured by the judicial mafia, most of its judges have had a reformist orientation that has embraced a concern with not just civil and political rights but also socioeconomic ones (Mietzner, 2010; Dressel and Mietzner, 2012). In 2013, the Constitutional Court's then Chairperson, Akil Mochtar, was arrested on corruption charges related to decisions he had made at the Court. Rather than allow the Court to flounder, President Yudhoyono issued a "regulation in lieu of a law" (perpu) that sought to restore the Court's reputation by changing the selection process and supervision arrangements for Court judges. Other courts that have developed relatively positive reputations during the post-New Order period are the anti-corruption courts (Butt, 2012b) and itinerant religious courts (Curnow, 2012).

The third point is that the emergence of these courts, in particular the Constitutional Court, as fair and effective has created a potentially effective legal pathway through which citizens and rights activists can seek to challenge government policies they believe infringe human rights - namely, judicial review of the constitutionality of laws. Indeed, the Constitutional Court has emerged as a key site in which citizens and activists have defended education-related rights, as one of our cases below illustrates. At the same time, other legal innovations such as citizen law suits, class actions and legal standing (all of which were rare, if not unheard of, during the New Order period) have opened up new ways of engaging with general courts and the Supreme Court (Gatot, 2007; Santosa, 2007; Susanti, 2008, p. 238) to accompany pre-existing mechanisms such as judicial review of regulations. As we will see below, a citizen law suit has been used effectively in one case related to the right to education.

\section{The politics of education policymaking in Indonesia}

During the New Order period, the Indonesian government neglected the education sector. While it substantially expanded the geographical reach of the education system and improved access to education, it invested much less in education than neighbouring countries did (World Bank, 1998, p. 111), and used the education system as a vehicle for propagating the state ideology, Pancasila, enforcing political control, and distributing patronage rather than encouraging independent and critical thinking (Leigh, 1999; Nugroho, 2005). The education bureaucracy and public schools and universities that dominated the education system became part of the larger franchise structure that characterised the New Order, the key feature of which was the sale of public office for private gain (McLeod, 2000). Captured by predatory bureaucrats, corruption and rent-seeking within the education system were rife (Irawan et al., 
This is an Accepted Manuscript of an article published by Taylor \& Francis in Asian Studies Review on 27 April 2015, available online:

http://www.tandfonline.com/doi/full/10.1080/10357823.2015.1025462

2004; Rosser and Joshi, 2013). Taken together, these three factors - underinvestment, a focus on political control, and corruption and rent-seeking - resulted in low educational quality (World Bank, 1998, p. 148) and serious problems with retention (World Bank, 1997, pp. 6869; 1998, p. 46).

The fall of the New Order in 1998 led over the following decade to significantly increased government spending on education and renewed efforts by the central and some local governments to implement free basic education. These changes reflected: 1) widespread recognition that government underinvestment in the sector under the New Order was a key reason for its low quality and student retention problems; 2) the fact that, as discussed above, the MPR incorporated explicit rights to education and to free basic education into the 1945 Constitution as part of the amendment process between 1999 and 2002; and 3) the political utility of free basic education, providing national and local-level politicians with a strong incentive to promote it. President Susilo Bambang Yudhoyono has been crucial in the latter respect, introducing a new program of school grants (generally known as BOS) in 2005 to cover "operational" costs of basic education such as those related to the registration of new students, the purchase of textbooks, the production of report cards, stationery, teacher development and training, remedial teaching programs, and examinations (Rosser and Joshi, 2013). For Yudhoyono, the political utility of BOS lay in both the electoral popularity of free basic education and the fact that additional resources at the school level enabled him to build a political base among locally influential figures such as school principals, teachers and local education officials. This was particularly beneficial for Yudhoyono given the institutional weakness of his electoral vehicle, the Democrat Party (Rosser and Joshi, 2013, p. 181).

At the same time, however, the 1997-98 economic crisis provided an opportunity for liberal government technocrats and their donor supporters (particularly the World Bank) to promote a shift towards a freer, more market-driven education system. In September 1998 the World Bank published a major report on Indonesia's education sector (World Bank, 1998) and, shortly thereafter, co-funded with the national development planning agency (Bappenas) a series of technocratic Task Forces on key education policy issues such as school-based management and decentralisation, public-private partnerships, education financing, and education reform (Jalal and Musthafa, 2001, pp. viii-X). Between them the 1998 Bank report and the Task Forces' reports mapped out a detailed neoliberal reform agenda for the country's education system. Over the next few years, the Bank and other donors provided loans and grants to the Indonesian government to support this policy agenda and issued further reports encouraging market-oriented reform (see, for instance, World Bank, 2004. Additional pressure for Indonesia to liberalise its education sector emerged in 2004-05 as a result of World Trade Organization negotiations on trade in services as part of the Doha Round.

The end result was the introduction during the late 1990s and the 2000s of a wide range of neoliberal education reforms including school-based management (SBM), minimum service standards (MSS) for education, teacher certification requirements, rationalisation of the school curriculum, a national exam, increased autonomy for educational institutions, and changes to national law providing for the opening up of the higher education system to foreign institutions.

These reforms have been challenged by rights activists and nationalist intellectuals who specialise in education issues. The former have been based, for the most part, at either NGOs in Jakarta - with Indonesia Corruption Watch (ICW) (a prominent anti-corruption organisation), ELSAM (a human rights organisation), the Indonesian Teachers' Association (IGI) (a professional organisation), and LBH Jakarta (a legal aid organisation) being particularly important in this respect - or networks of individuals and organisations closely 
This is an Accepted Manuscript of an article published by Taylor \& Francis in Asian Studies Review on 27 April 2015, available online:

http://www.tandfonline.com/doi/full/10.1080/10357823.2015.1025462

associated with these NGOs such as the Education Forum (which is closely aligned with LBH Jakarta) and Education Coalition (which is closely aligned with ICW). Nationalist education intellectuals have been based mainly at teacher training universities, in particular Jakarta National University, Taman Siswa (an educational institution founded as part of the nationalist struggle against Dutch colonialism) and the Institute for Education Reform at Paramadina University.

Committed to a radical populist agenda centred on notions such as social justice, human rights, clean government and national autonomy, ${ }^{7}$ both sets of individuals have argued that neoliberal education policy reform has threatened to commercialise and privatise education and, in so doing, make quality education unaffordable for Indonesia's poor and marginalised. This, in turn, they have suggested, has worsened social inequality (Irawan et al., 2004; Ridho, 2007; Darmaningtyas et al., 2009; Darmaningtyas and Subkhan, 2012) and undermined the role of education in promoting national resilience and identity (Soedijarto, 2008; Tilaar, 2012). In both cases, they have invoked the thinking of Ki Hadjar Dewantara, the founder of Taman Siswa, and drawn on populist critiques of neo-liberalism informed by dependency theory. ${ }^{8}$

To promote their cause, rights activists and nationalist intellectuals have pursued several activities simultaneously: raising public awareness about rights breaches through the media and book publication; lobbying public officials including especially members of the national parliament; and (typically when these have failed to produce desired policy changes) trying to change policy through the courts, in particular (but not only) the Constitutional Court. ${ }^{9}$ As we will see in detail below, the latter has proven a reasonably effective strategy in some cases, at least in getting the government to back away from extreme neoliberal policies if not perhaps in promoting realisation of the alternative vision of society implied by radical populism. ${ }^{10}$

\section{The Cases}

\section{Case 1: The national exam}

A national school exam has been a feature of Indonesia's education system for decades, although its name and nature have changed over time (Darmaningtyas and Subkhan, 2012, pp. 174-75). The New Order's version of the exam - known as the National Final Learning Evaluation (EBTANAS) - was characterised by low average scores, almost 100 per cent graduation rates, and widespread cheating, with the result that it provided "little or no control over the quality of graduates" (Oey-Gardner, 2000, p. 130; World Bank, 2004, p. 100). At the same time, because of exam fees imposed on students and corruption in exam management, it "drain[ed] considerable resources from students and their families, while providing a valuable source of income to those responsible for its administration" (Oey-Gardner, 2000, p. 128). Following the collapse of the New Order, government technocrats and their donor supporters moved to replace EBTANAS with a new examination system (Triaswati et al., 2001, pp. 9699; Umar, 2004).

The result was the introduction in 2002 of the National Final Exam (UAN), subsequently renamed the National Exam (UN) in 2005 (hereafter I refer simply to the national exam or UN). Administered at primary, junior secondary and senior secondary levels every year to students in their final year at these levels, it was envisaged that the UN would raise the quality of Indonesian education by changing students' and teachers' incentives. Under the UN, students' final results - and hence their ability to continue with their education 
This is an Accepted Manuscript of an article published by Taylor \& Francis in Asian Studies Review on 27 April 2015, available online:

http://www.tandfonline.com/doi/full/10.1080/10357823.2015.1025462

- would be dependent entirely on their national exam scores (in contrast to EBTANAS where final results were determined in part by school grades), giving them an incentive to perform better and teachers an incentive to teach better. This rationale was advanced explicitly by the two government figures most directly responsible for introducing the UN, Jusuf Kalla (2013), in 2002 the Coordinating Minister for People's Welfare (subsequently Vice-President from 2004 to 2009), and Jahja Umar (2004), then a senior official at this ministry.

As was the case with EBTANAS, the UN has been undermined by widespread cheating, often involving whole classes or schools with the encouragement of teachers and principals, and corruption in its administration (Arifin, 2012a; Hidayat et al., 2013). Although UN pass rates are monitored closely by the government and increases claimed to indicate improved educational quality, independent observers question the reliability of the results. ${ }^{11}$ Rights activists have been critical of the UN on the grounds that (i) it is unfair because the same exam is administered to all students at each year level, despite the fact that the quality and availability of education vary enormously across the Indonesian archipelago; and (ii) it infringes the rights of students who fail the exam and are unable to continue to the next level of education. Rather than pursue such a "high stakes" approach to examination, they have argued, the government should allow teachers to determine whether students progress to the next level as, they point out, is required by Law 20/2003. They have also pointed to the fact that the exam generates widespread stress and anxiety among students and, because of extensive cheating, undermines the integrity of the education system. They have questioned whether the benefits of the exam outweigh its costs (Suparman, 2007; Gale, 2010; Sarasvati, 2012).

By 2005-06, rights activists at LBH Jakarta, a prominent Jakarta-based legal aid NGO, and the Education Coalition, a Jakarta-based network of individuals and organisations concerned about education, were receiving large numbers of complaints from parents across the country. The parents claimed that their children were "victims of the national exam" because they had been unable to continue with their education after failing the exam, in breach of their right to education. ${ }^{12}$ LBH Jakarta and the Education Coalition had collaborated on an earlier failed effort to challenge the UN through a judicial review at the Supreme Court in 2004 (Rita and Planasari, 2004). ${ }^{13}$ Nevertheless, with parents mobilising against the national exam, activists at both organisations judged that they should mount another legal challenge, this time in the form of a citizens' law suit at the Central Jakarta District Court. They considered that this would be a more effective legal strategy than a class action or legal standing, the main alternative legal strategies available (Gatot, 2007). Lodging a judicial review request with the Constitutional Court was not a viable option because of the fact that the national exam was provided for in implementing regulations rather than Law $20 / 2003$, placing the issue outside the jurisdiction of the Constitutional Court.

Launched in 2006, the case involved 58 people, mostly parents of schoolchildren, as petitioners (penggugat), making it a much larger affair than the earlier case, which had involved only five education activists. LBH Jakarta provided the services of its lawyers pro bono and covered court costs - in other words, it provided the support structure required to translate the parents' concerns into legal mobilisation. ${ }^{14}$ In their submission to the Jakarta District Court (gugatan), the petitioners requested that the government change various aspects of the exam and issue a public apology for failing to protect citizens' rights to education and children's rights, especially those of children who had failed the exam and were consequently unable to continue their education. At the same time, LBH Jakarta and Education Coalition activists worked together to mobilise public opinion - more effectively than in the earlier case - by holding a public demonstration involving 300 students that gained widespread media attention and regularly engaging with the media in relation to the 
This is an Accepted Manuscript of an article published by Taylor \& Francis in Asian Studies Review on 27 April 2015, available online:

http://www.tandfonline.com/doi/full/10.1080/10357823.2015.1025462

case. They also recruited Sophia Latjuba, one of the country's most popular singers and actresses, including her in the public demonstration and the citizen law suit as one of the 58 petitioners. ${ }^{15}$

According to one member of the Education Coalition, the petitioners felt that the Court's judges were on their side from the outset. ${ }^{16}$ The chair of the Court's council of judges, Adriani Nurdi subsequently became the first woman to head the Jakarta District Court, declaring at her inauguration that she would transform it into a modern court committed to social justice (Nurmasari, 2007), an indication that she had a reformist orientation. In 2007, the Court ruled in the petitioners' favour, stating that the government had been "negligent in providing fulfilment and protection of the human rights of its citizens who were victims of the national exam, especially the right to education and children's rights" (HukumOnline, 2007, p. 30). It further instructed the government to improve teacher quality, enhance school infrastructure and facilities, and provide better information about the national exam before issuing new regulations on the national exam - in other words, before running it again (HukumOnline, 2007). Amidst continued lobbying against the national exam by education activists (Ridho, 2007), increased media reporting on the issue, growing public angst over the issue, and calls for reform from the national parliament, the government appealed the decision to the Jakarta High Court in 2008 and the Supreme Court in 2009, but it lost on both occasions (Jakarta High Court, 2008; Supreme Court, 2009).

None of the three courts (Jakarta District Court, Jakarta High Court and the Supreme Court) ruled that the government should discontinue the UN. Nevertheless the court decisions provoked it into introducing reforms that served to significantly reduce UN failure rates. In 2010, it introduced a supplementary exam (ujian ulangan), giving failed students a second chance to pass, and in 2011 it changed the method of calculating students' final results to include school results, giving teachers some say in whether students progress to the next educational level. Overall pass rates have reached almost 100 per cent as a result, thus dramatically reducing the number of national exam "victims". ${ }^{17}$ Following its judgment, the Supreme Court advised the government that these reforms were sufficient to address the Court's concerns and permit it to continue implementing the exam (Pratisto et al., 2009).

In the wake of these changes, rights activists have continued to publicly campaign against the UN (Arifin, 2012b; Darmaningtyas and Subkhan, 2012). With pass rates at almost 100 per cent, the focus of public debate has shifted away from the "victimisation" of students and rights issues towards ongoing cheating and corruption in exam administration (see, for instance, Septian et al., 2013). In May 2013, after widespread media coverage of delays and irregularities in the 2013 national exam and public calls for the Minister of Education and Culture, Muhammad Nuh, to resign, the head of the Ministry of Education and Culture's (MoEC's) Research and Development Unit (which plays a key role in managing the exam) stood down from his position and the government withdrew primary responsibility for managing the primary school exam from the National Education Standards Board (BSNP). The latter change was widely reported as a decision to cancel the primary school exam (Jakarta Globe, 2013; Radio Australia, 2013), but it remains to be seen whether this will in fact occur.

In summary, then, the parents who felt their children had been victimised by the national exam were able to achieve a series of court victories defending their children's rights - and ultimately changes in government policy - because (i) they had access to a SSLM in the form of LBH Jakarta, its lawyers, and financial resources; (ii) they encountered reformist judges in court; and (iii) they engaged in political activities outside the court that mobilised public and political opinion in their favour, creating a climate in which even the Supreme Court, arguably the country's most inefficient and corrupt court, appeared unable to rule 
This is an Accepted Manuscript of an article published by Taylor \& Francis in Asian Studies Review on 27 April 2015, available online:

http://www.tandfonline.com/doi/full/10.1080/10357823.2015.1025462

against them and the government felt compelled to amend key aspects of its policies in relation to the exam.

\section{Case 2: Educational institution autonomy}

Under the New Order, educational institutions were essentially part of the bureaucracy, meaning that the central government and, in particular, MoEC exercised tight control over their affairs (Brodjonegoro, 2012, p. 91). Following the fall of the New Order, government technocrats and their donor allies argued strongly that educational institutions should be granted greater autonomy from government in order to help them mobilise the funding required to deliver quality services, ensure intellectual freedom, and respond effectively to the demands of students and other clients (World Bank, 1998, p. 93; Jalal and Musthafa, 2001, p. 230; Brodjonegoro, 2012). The result was the introduction of an article in Law 20/2003 on a National Education System requiring that all public and private educational institutions should become "education legal entities" (badan hukum pendidikan, BHP), that these entities should operate on a not-for-profit basis, and that they should manage their financial affairs autonomously (Article 53). This article was then transformed into a dedicated law in early 2009: Law 9/2009 on BHP.

Rights activists strongly criticised these reforms. They argued that a change in the legal status of educational institutions to BHP would (i) result in the state "avoiding its obligation to fund education"; (ii) cause tuition fees to skyrocket, particularly at higher education institutions (HEIs), making higher education unaffordable for many people; and in so doing (iii) undermine citizens' rights to education and worsen inequality (Irawan, 2007; Surakhmad, 2007; Darmaningtyas et al., 2009). During parliamentary debates over the draft BHP law, parent groups, university student organisations and their allies in NGOs such as ICW and LBH Jakarta and nationalist intellectual circles lobbied hard against the proposed change, holding public discussions on the issue of educational institution autonomy, making comments to the press, and, in the case of student groups, organising public protests (Darmaningtyas et al., 2009, pp. 285-306). They also published widely on the issue in the mass media and books (Irawan, 2007; Surakhmad, 2007; Darmaningtyas et al., 2009).

In this context, three groups of parents decided to challenge Law 9/2009 in the Constitutional Court in 2009, with some also giving attention to Article 53 of Law 20/2003. The first of these was supported by the Education Forum, a network of individuals and organisations concerned about education rights that had emerged out of the struggle over the national exam court case and a split in the Education Coalition. It was supported by legal representation from Pohan and Goei, a private law firm headed by former LBH Jakarta activist, Gatot Goei, the lead lawyer on the citizen law suit examined in the previous section. A second group of parents was supported by the Education Coalition and represented by lawyers from a range of NGOs including ICW, ELSAM and LBH Masyarakat (a legal aid NGO). In both cases, the lawyers provided their services pro bono. ${ }^{18}$ The third group of parents were associated with school-specific parent networks and represented themselves.

Two other groups lodged Constitutional Court challenges to the law at the same time. The first of these, university students associated with the Indonesian Islamic Students' Movement (PMII), shared the same broad concerns about Law 9/2009 as the parent groups above. The second, charitable foundations (yayasan) that owned private educational institutions supported by their industry association (the Association of Indonesian Private University Implementing Bodies, or ABPPTSI), had different concerns about the law. Specifically, they feared a loss of control over their HEIs if the latter were granted separate legal status ${ }^{19}$ and, with that, the financial benefits associated with running them. 
This is an Accepted Manuscript of an article published by Taylor \& Francis in Asian Studies Review on 27 April 2015, available online:

http://www.tandfonline.com/doi/full/10.1080/10357823.2015.1025462

Alternatively, if yayasan were reconstituted as BHP, they feared tougher reporting and transparency requirements ${ }^{20}$ and potential disruption to their activities and those of their educational institutions. ${ }^{21}$ There was some mutually supportive interaction between these different groups: for instance, ICW activists claim that they provided the yayasan with assistance in formulating their case. ${ }^{22}$

In court, the parent groups, university student groups and their lawyers presented their views on the BHP law, pointing, among other things, to ways in which the proposed change in the legal status of educational institutions breached citizens' Constitutional rights to education and free basic education. They were supported in making their case by testimonies by nationalist intellectuals including Darmaningtyas, Winarno Surakhmad and Soedijarto. In 2010, the Constitutional Court granted them a partial victory, ruling that both Article 53(1) in Law 20/2003 (the part of the Article stating that educational institutions should be BHP) and Law 9/2009 were unconstitutional and null and void, but doing so on grounds that rejected these groups' arguments that a change to BHP status represented a breach of citizens' rights to education and free basic education (Mahkamah Konstitusi, 2010, pp. 371-404). Instead, the court placed greater emphasis on the law's breaches of the right to legal certainty and the problems uniform legal status would create for continued delivery of educational services and achievement of national educational objectives - that is, the core concerns of the yayasan and their industry association, ABPPTSI. Rights activists were not perturbed by this, seeing such legal arguments as a strategic decision on the Constitutional Court's part for supporting rights causes but without running the political risk associated with a judgment explicitly relying on rights-based arguments. ${ }^{23}$

In delivering this judgment, it is difficult to know how much the Constitutional Court was influenced by strict legal considerations and how much by popular sentiment as mobilised by parent groups, university student organisations and their NGO allies through their lobbying and media work. It is widely believed that Mahfud MD, the Court's chairperson (ketua), used his time in charge of the Court to enhance his personal popularity, as a basis for his current efforts to run for the presidency in 2014. This suggests that the latter factor may have had some bearing on the case, notwithstanding the Court's rejection of much of the legal argument advanced by parent and student groups and their lawyers.

As with the national exams case, the effect of the Constitutional Court's decision was to force the government back to the policy drawing board and ultimately to water down its approach. As a stop-gap measure, it made changes to existing regulations to provide a legal basis for the continued operation of several elite state universities that had already changed their status to state-owned legal entity (BHMN), a legal status constructed as a precursor to BHP to provide these universities with greater autonomy. In conjunction with the DPR, MoEC then produced a new law on Higher Education (Law 12/2012) that reaffirmed the principle of autonomy, but because of its sub-sectoral focus, only for HEIs. This law was, at the time of writing, also subject to a Constitutional Court challenge brought by student activists at Andalas University in Padang.

In summary, then, parent groups who opposed Article 53 in Law 20/2003 and Law 9/2009 were able to achieve a significant court victory - albeit one that rejected a link between educational institution autonomy and breaches of the rights to education and free basic education - and ultimately changes in government policy - because (i) they had access to a SSLM in the form of various NGOs, their lawyers and financial resources; (ii) they took their case to a court with activist judges; (iii) their NGO supporters cooperated with other groups that shared the same objectives but, as it turned out, had a stronger legal case in the eyes of the Constitutional Court; and (iv) they helped to create a broader political climate that 
This is an Accepted Manuscript of an article published by Taylor \& Francis in Asian Studies Review on 27 April 2015, available online:

http://www.tandfonline.com/doi/full/10.1080/10357823.2015.1025462

was favourable to their case and to policy change through political mobilisation outside the court.

\section{Conclusion}

This paper has sought to contribute to the debate surrounding the impact of JLFPHR on the realisation of human rights in developing countries - focusing specifically on the translation of these frameworks into government policy - by analysing a set of recent Indonesian court cases related to the right to education. It has argued that citizens involved in these cases were able to secure rights-friendly court decisions - and ultimately changes in government policy for three reasons. First, they had access to SSLMs in the form of legal aid, human rights and anti-corruption NGOs, their lawyers and financial resources. In both the national exams and BHP cases, parent groups are unlikely to have mobilised for legal action in the first place without the support of NGOs, given the modest financial means and organisational capacities of the actors involved. Latjuba possibly may have had the financial resources required to launch and sustain the national exam law suit herself but it is notable that she was only brought into the case through personal networks once a decision had been made to go to court. ${ }^{24}$ Second, these citizens encountered sympathetic judges willing to challenge government policy and upset powerful policy actors either because they took their cases to the Constitutional Court, a court known for its progressive views on rights issues, or were allocated such judges in regular courts. Finally, they engaged in political mobilisation alongside their legal activities that secured public and political support for their respective causes, and in so doing created a political climate conducive to judicial activism and policy change.

In emphasising these factors, this paper provides support to the third group of scholars mentioned at the outset of the paper - that is, those who have argued that the impact of JLFPHR on rights realisation through courts is contingent upon the presence of activist judges and SSLMs (with regards to the latter, at least in contexts in which court cases are costly and citizens consequently do not have direct access to the court system). JLFPHR are not, as advocates of rights-based approaches to development (RBAs) would have it, naturally self-activating. Nor are they a waste of time except to the extent that they precipitate political mobilisation around rights issues, as law and social movements scholars have suggested. Rather, JLFPHR can promote the realisation of human rights - and in particular through legal mobilisation/use of the court system - as long as activist judges are in place and citizens have access to SSLMs.

At the same time, however, the paper also illustrates that legal and political mobilisation do not occur independently of one another, as some of the literature assumes, but rather can work hand in hand to promote favourable court judgments and changes in government policy. In both the national exam and BHP cases, the activists and NGOs supporting legal mobilisation by parent groups were also very active in organising public protests, engaging with the media, lobbying parliament and engaging in other forms of political mobilisation. And it seems likely that this activity influenced judicial decisionmaking, either by empowering activist judges to make rights-friendly decisions or by creating a broader political climate in which non-activist judges, particularly at the Supreme Court, felt they had to do likewise.

As such, the findings here suggest that we need to think in terms of support structures for legal and political mobilisation rather than just the former. To focus solely on the way in which cause lawyers and their organisations facilitate legal mobilisation ignores (i) the important role that political mobilisation can play, both directly and (as in the cases here) via 
its impact on the outcome of court cases, and (ii) the role of these lawyers and their organisations in helping ordinary citizens to organise politically. Some scholars have questioned whether SSLMs have played a significant role in "rights revolutions" in the developing world, particularly where courts have been designed in such a way as to allow citizens easy and effective direct access to courts (Wilson, 2009; 2011). Here, by contrast, it is argued that the concept not only has analytical value but needs to be broadened to encompass other forms of mobilisation.

What are the policy implications of these findings? In short, they suggest that we should be cautiously optimistic about the impact of JLFPHR on the realisation of human rights even in contexts such as Indonesia, where the court system is, in general terms, weak, as long as the right conditions are in place. The policy changes they yield may not be fundamental in the short term. For instance, as we have seen, the Indonesian government has continued to carry out the national exam and support university autonomy through new laws and regulations. In making these revisions, it has backed away from more extreme initial positions that infringed citizens' rights to education. This provides some hope that more farreaching changes and rights realisation might be possible in the future and indicates the potential of JLFPHR. To realise this potential, however, JLFPHR need to be accompanied by SSLMs, judicial activism and the employment of strategies that blend legal and political mobilisation. In policy terms, the implication is that introducing JLFPHR is not enough on its own: we also need these other variables that serve to activate the rights contained in JLFPHR.

There are two main caveats to these various conclusions. First, there may be a ruralurban divide in terms of citizens' ability to mobilise formal law to promote their rights. According the World Bank (2015), "[v]illage leaders and traditional leaders are the primary dispute resolution actors in Indonesia, playing an active role in over 75\% of disputes". To the extent that rural poor people face higher transaction costs in forging links to national NGOs and cause lawyers and using national courts as opposed to traditional village-level justice mechanisms, it is reasonable to conclude that JLFPHR will work better for the urban middle classes and poor (particularly those in the capital) than the rural poor. Consistent with this hypothesis, the cases examined here both involved actors that were predominantly from the national capital, reflecting the fact that the Constitutional and Supreme Courts and many leading NGOs are located there.

Second, there may also be cross-sectoral differences in terms of citizens' ability to mobilise formal law to promote their rights. It is possible, for instance, that citizens find it easier to engage in collective action - specifically legal and political mobilisation - around education rights than health rights because school and university life bring them together in ways that health centres and hospitals do not. The fact that recipients of health services are generally sick - whereas parents of schoolchildren are generally healthy - is another relative barrier to collective action in the health sector. ${ }^{25}$ To the extent that such cross-sectoral differences exist, one can expect the impact of JLFPHR on the realisation of rights to vary by sector as well. Further research is needed to assess whether this is in fact the case and in turn the implications for the potential of JLFPHR to promote the realisation of rights across all sectors.

\section{Acknowledgments}

I wish to thank Wahyudi Djafar and Donni Edwin for research assistance during fieldwork for this paper and two anonymous reviewers for their comments on an earlier draft of the paper. This work was supported by the Australian Research Council under grant number FT110100078. 
This is an Accepted Manuscript of an article published by Taylor \& Francis in Asian Studies Review on 27 April 2015, available online:

http://www.tandfonline.com/doi/full/10.1080/10357823.2015.1025462

\section{References}

Arifin, Habe (2012a) Kecurangan Sistematis, in Habe Arifin (ed.), Buku hitam ujian nasional, pp. 289-91 (Yogyakarta: Resist Press).

Arifin, Habe (ed.) (2012b) Buku hitam ujian nasional (Yogyakarta: Resist Press).

ASEAN Law Association (2005) Legal systems in ASEAN. Available at http://www.aseanlawassociation.org/legal.html, accessed 1 June 2013.

Aspinall, Edward (2005) Opposing Suharto: Compromise, resistance and regime change in Indonesia (Stanford: Stanford University Press).

Asshiddiqie, Jimly (2006) Hukum acara: Pengujian undang-undang (Jakarta: Konstitusi Press).

Baxi, Upendra (1985) Taking suffering seriously: Social action litigation in the Supreme Court of India. Third World Legal Studies 4, pp. 107-32.

Bhagwati, P.N. (1984) Judicial activism and public interest litigation. Columbia Journal of Transnational Law 23, pp. 561-77.

Brinks, Daniel and Varun Gauri (2008) A new policy landscape: Legalizing social and economic rights in the developing world, in Varun Gauri and Daniel Brinks (eds), Courting social justice: Judicial enforcement of social and economic rights in the developing world, pp. 303-52 (Cambridge: Cambridge University Press).

Brodjonegoro, Satrio (2012) Higher education reform, in Sulistyowati Irianto (ed.), Otonomi perguruan tinggi: Suatu keniscayaan, pp. 78-96 (Jakarta: Yayasan Obor Indonesia).

Butt, Simon (2012a) Indonesia's Constitutional Court: Conservative activist or strategic operator?, in Bjorn Dressel (ed.), Judicialisation of politics in Asia, pp. 98-116 (Milton Park: Routledge).

Butt, Simon (2012b) Corruption and law in Indonesia (London: Routledge).

Chalmers, Ian and Vedi Hadiz, eds. (1997) The politics of economic development in Indonesia: Contending perspectives (London: Routledge).

Crouch, Harold (2009) Political reform in Indonesia after Soeharto (Singapore: Institute of Southeast Asian Studies).

Curnow, Jayne (2012) Legal support structures and the realisation of Muslim women's rights in Indonesian law. Paper presented at the Workshop on Law, Politics and the Realisation of Human Rights in Developing Countries, University of Adelaide, October. 
This is an Accepted Manuscript of an article published by Taylor \& Francis in Asian Studies Review on 27 April 2015, available online:

http://www.tandfonline.com/doi/full/10.1080/10357823.2015.1025462

Darmaningtyas and Edi Subkhan (2012) Manipulasi kebijakan pendidikan (Yogyakarta: Resist Book).

Darmaningtyas, Edi Subkhan and Fahmi-Panimbang (2009) Tirani kapital dalam pendidikan: Menolak UU BHP (badan hukum pendidikan) (Yogyakarta: Pustaka Yashiba and Damar Press).

Dressel, Bjorn and Marcus Mietzner (2012) A tale of two courts: The judicialization of electoral politics in Asia. Governance 25(3), pp. 391-414.

Epp, Charles (1996) Do Bills of Rights matter? The Canadian Charter of Rights and Freedoms. American Political Science Review 90(4), pp. 765-79.

Epp, Charles (1998) The rights revolution: Lawyers, activists, and Supreme Courts in comparative perspective (Chicago: University of Chicago Press).

Epp, Charles (2010) Making rights real: Activists, bureaucrats, and the creation of the legalistic state (Chicago and London: University of Chicago Press).

Gale, Bruce (2010) Exam system fails to pass muster. Straits Times, 2 April.

Gatot (2007) Gugatan citizen law suit terhadap kebijakan ujian nasional, in Irianto Ridho (ed.), Menggugat ujian nasional, pp. 101-16 (Jakarta: Teraju).

Goodpaster, Gary (2002) Reflections on corruption in Indonesia, in Tim Lindsey and Howard Dick (eds), Corruption in Asia: Rethinking the governance paradigm, pp. 87-108 (Sydney: The Federation Press).

Hidayat B., H. Wasono, A. Siswadi and Ivansyah (2013) Bursa kunci sebelum hari penentuan. Tempo, pp. 42-43.

Hing, Lee (1978) The Taman Siswa in postwar Indonesia. Indonesia 25, pp. 41-59.

HukumOnline (2007) Putusan Nomor 228/PDT.G/2006/PN.JKT.PST. Available at http://www.hukumonline.com/pusatdata/detail/lt4c1885f340a9f/node/lt49f802c936fc9/putusa n-pengadilan-negeri-jakarta-pusat-no-228_pdt.g_2006_pn.jkt.pst-kristiono-vs.-presidenrepublik-indonesia, accessed 3 June 2013.

Ida, Laode (2010) Negara mafia (Yogyakarta: Galang Press).

Irawan, Ade (2007) Ancaman RUU badan hukum pendidikan. Seputar Indonesia, 18 September. Available at http://www.antikorupsi.org/antikorupsi/?q=node/11316, accessed 28 January 2013.

Irawan, Ade, Eriyanto, Luky Djani and Agus Sunaryanto (2004) Mendagangkan sekolah (Jakarta: Indonesia Corruption Watch). 
This is an Accepted Manuscript of an article published by Taylor \& Francis in Asian Studies Review on 27 April 2015, available online:

http://www.tandfonline.com/doi/full/10.1080/10357823.2015.1025462

Jakarta Globe (2013) Education ministry to clean house after national exam fiasco. 13 May. Available at http://www.thejakartaglobe.com/news/education-ministry-to-clean-house-afternational-exam-fiasco/, accessed 19 May 2013.

Jakarta High Court (2008) Putusan nomor 377/PDT/2007/PT.DKI.

Jalal, Fasli and Bachrudin Musthafa (2001) Education reform in the context of regional autonomy: The case of Indonesia (Jakarta: MoEC and World Bank).

Joshi, Anuradha (2010) Do rights work? Law, activism, and the employment guarantee scheme. World Development 38(4), pp. 620-30.

Kalla, Jusuf (2013) Ujian nasional. Kompas, 2 May.

Keith, Linda, C. Neal Tate and Steven Poe (2009) Is the law a mere parchment barrier to human rights abuse? The Journal of Politics 71(2), pp. 644-60.

Khan, Irene (2009) The unheard truth: Poverty and human rights (New York: W.W. Norton and $\mathrm{Co}$ ).

Leigh, Barbara (1999) Learning and knowing boundaries: Schooling in New Order Indonesia. Sojourn: Journal of Social Issues in Southeast Asia 14(1), pp. 34-56.

Mahkamah Konstitusi (2010) Putusan nomor 11-14-21-126 dan 136/PUU-VII/2009.

McCann, Michael (1994) Rights at work (Chicago: University of Chicago Press).

McLeod, Ross (2000) Soeharto's Indonesia: A better class of corruption. Agenda 7(2), pp. 99-112.

McVey, Ruth (1967) Taman Siswa and the Indonesian national awakening. Indonesia 4, pp. 128-49.

Mietzner, Marcus (2010) Political conflict resolution and democratic consolidation in Indonesia: The role of the Constitutional Court. Journal of East Asian Studies 10, pp. 397424.

Nugroho, Heru (2005) The political economy of higher education: The university as an arena for the struggle for power, in Vedi Hadiz and Daniel Dhakidae (eds), Social science and power in Indonesia, pp. 143-65 (Singapore and Jakarta: ISEAS and Equinox).

Nurmasari, Indah (2007) Adriani Nurdin ketua PN Jakarta Pusat. VHRmedia. Available at http://www.vhrmedia.com/vhr-news/berita-detail.php?.g=news\&.s=berita\&.e=983, accessed 3 June 2013.

Oey-Gardner, Mayling (2000) Schooling in a decentralised Indonesia: New approaches to access and decision-making. Bulletin of Indonesian Economic Studies 36(3), pp. 127-34. 
This is an Accepted Manuscript of an article published by Taylor \& Francis in Asian Studies Review on 27 April 2015, available online:

http://www.tandfonline.com/doi/full/10.1080/10357823.2015.1025462

Pompe, Sebastian (2005) The Indonesian Supreme Court: A study of institutional collapse (Ithaca: Southeast Asia Programme, Cornell University).

Pratisto S., Anthony, and S. Turido (2009) Guru ditekan, soal ujian bocor, Gatra 9 December, pp. 86-87.

Radio Australia (2013) Pemerintah siapkan format baru UN untuk siswa SD. 16 May. Available at http://www.radioaustralia.net.au/indonesian/2013-05-16/pemerintah-siapkanformat-baru-un-untuk-siswa-sd/1132028, accessed 19 May 2013.

Rajagopal, Balakrishnan (2012) Limits of law in counter-hegemonic globalization: The Indian Supreme Court and the Narmada Valley struggle (New Delhi: Centre for the Study of Law and Governance, Jawaharlal Nehru University).

Ridho, Irianto, ed. (2007) Menggugat ujian nasional (Jakarta: Teraju).

Rita, Maria and Sita Planasari (2004) 5 guru ajukan uji materiil keputusan Menteri Pendidikan. Koran Tempo, 13 April. Available at http://www.infoanda.com/followlink.php?lh=BwRWBFcBAlAD, accessed 19 May 2013.

Rosenberg, Gerald (1991) The hollow hope: Can courts bring about social change? (Chicago: University of Chicago Press).

Rosser, Andrew and Jayne Curnow (forthcoming) Legal mobilisation and access to justice in Indonesia: Insights from the struggle over international standard schools.[more publication details?]

Rosser, Andrew and Anuradha Joshi (2013) From user fee to fee free: The politics of realising universal free basic education in Indonesia. Journal of Development Studies 49(2), pp. $175-89$.

Santosa, Mas Achmad (2007) Class actions in Indonesia. Available at http://globalclassactions.stanford.edu/content/class-actions-indonesia, accessed 1 June 2013.

Sarasvati, Dita (2012) The national examination and how it determines student futures: A case study through personal experience in working with children who failed the national examination, in Habe Arifin (ed.), Buku hitam ujian nasional, pp. 225-59 (Yogyakarta: Resist Books).

Scheingold, Stuart (1974) The politics of rights: Lawyers, public policy, and political change, $2^{\text {nd }}$ edition (Ann Arbor: University of Michigan Press).

Septian A., Sundari, S. Movementi, W. Purnomo, A. Sandi, and M. Permana (2013) Bocor soal kantor menteri. Tempo, 5 Mei, pp. 34-38.

Silverstein, Helena (2003) The symbolic life of law: The instrumental and the constitutive in Scheingold's The politics of rights. International Journal for the Semiotics of Law 16(4), pp. 407-23. 
This is an Accepted Manuscript of an article published by Taylor \& Francis in Asian Studies Review on 27 April 2015, available online:

http://www.tandfonline.com/doi/full/10.1080/10357823.2015.1025462

Soedijarto (2008) Landasan dan arah pendidikan nasional kita (Jakarta: Kompas).

Suparman (2007) Menyoal PP standar nasional pendidikan, in Irianto Ridho (ed.), Menggugat ujian nasional, pp. 60-65 (Jakarta: Teraju).

Supreme Court (2009) Putusan nomor No.2596 K/PDT/2008.

Surakhmad, Winarno (2007) Kriminalisasi pendidikan. Kompas, 2 May. Available at http://educationwatch-unj.blogspot.com.au/2012/12/kriminalisasi-pendidikan.html, accessed 28 January 2013.

Susanti, Bivitri (2008) The implementation of the rights to health care and education in Indonesia, in Varun Gauri and Daniel Brinks (eds), Courting social justice: Judicial enforcement of social and economic rights in the developing world, pp. 224-67 (Cambridge: Cambridge University Press).

Thoolen, Hans (1987) Indonesia and the rule of law: Twenty years of the "New Order" government: A study (London: Pinter).

Tilaar, H.A.R. (2012) Kaleidoskop pendidikan nasional: Kumpulan karangan (Jakarta: Kompas).

Triaswati, Nina et al. (2001) Financing education: Implications for decentralization, in Fasli Jalal and Bachrudin Musthafa (eds), Education reform in the context of regional autonomy: The case of Indonesia, pp. 33-130 (Jakarta: MoEC and the World Bank).

Umar J. (2004) Pendidikan nasional dalam ujian. Media Indonesia, 4 April and 5 May.

Wilson, Bruce (2009) Institutional reform and rights revolutions in Latin America: The cases of Costa Rica and Columbia. Journal of Politics in Latin America 1(2), pp. 59-85.

Wilson, Bruce (2011) The causes and consequences of health rights litigation in Costa Rica, in Alicia Yamin and Siri Gloppen (eds), Health rights in comparative perspective, pp. 13254 (Cambridge: Harvard University Press).

World Bank (1997) Indonesia: Sustaining high growth with equity (Washington, DC: World Bank).

World Bank (1998) Education in Indonesia: From crisis to recovery (Washington, DC: World Bank).

World Bank (2004) Education in Indonesia: Managing the transition to decentralization (Washington, DC: World Bank).

World Bank (2015) Law and justice in Indonesia. Available at http://web.worldbank.org/WBSITE/EXTERNAL/COUNTRIES/EASTASIAPACIFICEXT/0, 
This is an Accepted Manuscript of an article published by Taylor \& Francis in Asian Studies Review on 27 April 2015, available online:

http://www.tandfonline.com/doi/full/10.1080/10357823.2015.1025462

,print:Y isCURL:Y contentMDK:23192809 pagePK:146736 piPK:146830 theSitePK:226 301,00.html, accessed 25 February 2015.

\footnotetext{
Notes

${ }^{1}$ According to Wilson (2009; 2011) superior courts in these countries were accessible and cheap because they abandoned high levels of judicial formality, adopted broad definitions of standing, removed barriers to access, and resolved cases quickly. The cost of launching court cases in Indonesia - even at the Constitutional Court which has broad definitions of standing and no court fees - means that Indonesia does not represent the same sort of context.

${ }^{2}$ Rosser and Joshi (2013) have already touched on the second stage, particularly in their examination of problems in school-level governance and efforts by parents to pursue rights breaches by principals, teachers and local education officials through judicial and other processes.

${ }^{3}$ In its original form, the 1945 Constitution was the country's Constitution between 1945 and 1949 and from 1959 to 1999. It has remained the country's Constitution in amended form since revisions in 1999-2002.

${ }^{4}$ The New Order did not consider this provision to provide for a right to education, judging from the content of Law 2/1989 on a National Education System. See especially Article 1(1) which suggests that instruction is merely one means of providing education.

${ }^{5}$ The Elucidation to Law 2/1989 stated that "Indonesian citizens have a right to obtain an education at all stages of their lives", a statement more consistent with a right to education, but the Elucidation is not formally part of the law.

${ }^{6}$ See Crouch (2009, pp. 191-241) for an analysis of the politics surrounding judicial reform efforts.

${ }^{7}$ See Chalmers and Hadiz (1997) for a detailed discussion of the radical populist tradition in Indonesian politico-economic thinking.

${ }^{8}$ On Ki Hadjar Dewantara and Taman Siswa, see McVey (1967) and Hing (1978).

${ }^{9}$ Although many Indonesian rights activists are qualified lawyers, they have not been constrained by a sense that lawyers should avoid engagement in political affairs. Rather, they have seen the law as, to quote Rajagopal (2012, p. 3), a "space for resistance". The reasons for this are beyond the scope of this paper but doubtless include the fact that human rights lawyers played a key role in opposing the New Order (Aspinall, 2005) and remain a key oppositional force.

${ }^{10}$ Other cases that have ended up in court include those related to "international standard schools" (which rights activists won) and school textbooks (which they lost). See Rosser and Curnow (forthcoming) on the first of these cases.

${ }^{11}$ Interviews with a former Ministry of Education and Culture official and a foreign education consultant, Jakarta, May and June 2013 respectively.

${ }^{12}$ Interviews with Suparman, the then Coordinator of the Education Coalition, and Muhammad Isnur, currently Head of Research and Development at LBH Jakarta, Jakarta, May 2013.

${ }^{13}$ Interviews with Suparman, Ade Irawan and Lody Paat. The latter two were respectively Secretary and ViceCoordinator of the Education Coalition at the time of the Supreme Court judicial review case, Jakarta, May 2013.

${ }^{14}$ Interview with Gatot Goei, the lead LBH Jakarta lawyer on the citizen lawsuit, and Muhammad Isnur, Jakarta, May 2013.

${ }^{15}$ Interview with Gatot Goei, Jakarta, May 2013.

${ }^{16}$ Interview with Suparman, Jakarta, May 2013.

${ }^{17}$ It must be conceded that continued cheating has almost certainly contributed to this outcome as well as the reforms.

${ }^{18}$ Interviews with activists at ELSAM, ICW and LBH Jakarta, Jakarta, May 2013 and Gatot Goei, a lawyer at Pohan and Goei law firm, Jakarta, May 2013.

${ }^{19}$ Prior to Law 9/2009 on BHP, the yayasan itself constituted the legal entity, not the HEI.

${ }^{20}$ Interview with Anies Baswedan, Rector of Paramadina University and Head of Indonesia Mengajar, Jakarta, November 2012. In September 2006, the yayasan launched a Constitutional Court case against Article 53 of Law 20/2003, although this proved premature. In early 2007, the Court decided that it could not rule on the constitutionality of Article 53 until a BHP law had been enacted. See Constitutional Court Decision No. 21/PUU-IV/2006.

${ }^{21}$ This potential emerged, according to the yayasan, because a change in legal status would cause uncertainty vis-à-vis employment relationships and the ownership and use of yayasan assets (these cannot be transferred to
} 
This is an Accepted Manuscript of an article published by Taylor \& Francis in Asian Studies Review on 27 April 2015, available online:

http://www.tandfonline.com/doi/full/10.1080/10357823.2015.1025462

other parties under Indonesian law) and require yayasan to secure government approval for changes to their Articles of Association. See Mahkamah Konstitusi (2010, p. 133, pp. 171-72).

${ }^{22}$ Interview with Ade Irawan, Jakarta, November 2009.

${ }^{23}$ Interview with Wahyudi Djafar, ELSAM, Jakarta, June 2013.

${ }^{24}$ Interview with Gatot Goei, Jakarta, May 2013.

${ }^{25}$ I have benefited enormously from conversations with Anu Joshi on these points. 


\section{University Library}

\section{- M M I N E R VA A gateway to Melbourne's research publications}

Minerva Access is the Institutional Repository of The University of Melbourne

Author/s:

Rosser, A

Title:

Law and the Realisation of Human Rights: Insights from Indonesia's Education Sector

Date:

2015-04-03

Citation:

Rosser, A. (2015). Law and the Realisation of Human Rights: Insights from Indonesia's Education Sector. ASIAN STUDIES REVIEW, 39 (2), pp.194-212. https:// doi.org/10.1080/10357823.2015.1025462.

Persistent Link:

http://hdl.handle.net/11343/127209 